\title{
IMPLEMENTASI RENCANA PELAKSANAAN PEMBELAJARAN (RPP) DALAM SEKOLAH DASAR
}

\author{
Putri Salsabilla Sulistiyani $^{1}$, Ina Magdalena ${ }^{2}$, Serly Anggraeni ${ }^{3}$, Nurjamilah Selvia ${ }^{4}$ \\ Universitas Muhammadiyah Tangerang, Indonesia \\ putrisalsabilla1504@gmail.com, inapgsd@gmail.com, serlyanggraeni86@gmail.com, \\ milaselvia0810@gmail.com
}

Received: 25-01-2021

Revised: 13-02-2021

Accepted: 21-02-2021

\section{Abstract}

This study aims to describe the process and results of the implementation of the Learning Implementation Plan (RPP), as well as to find out what learning resources are appropriate to achieve learning outcomes and the factors that can influence the implementation of lesson plans in elementary school SDN Kramat 1. This type of research is qualitative research. . Data were collected using in-depth interviews, observations and describing the implementation of the Learning Implementation Plan (RPP). The lesson plan is very much needed in line with the various styles of learning media development and learning resources around the school that can be used by teachers to support the learning process. The results of this study indicate that, the implementation of the Learning Implementation Plan in Elementary Schools is carried out in an integrated manner, the steps of the teacher in applying the lesson plans, the sources and media used at the time of teaching, the factors that influence the implementation of the lesson plans and are implemented according to the lesson plans. The results of this study are expected to be useful and become a reference for educators and education staff to make innovations in order to improve the quality of student learning in schools.

Keyword : RPP; implementation; learning

\begin{abstract}
Abstrak
Penelitian ini betujuan mendeskripsikan proses dan hasil implementasi Rencana Pelaksanaan Pembelajaran (RPP), serta mengetahui sumber-sumber belajar apa saja yang tepat untuk mencapai hasil pembelajaran dan faktor yang dapat mempengaruhi implementasi RPP disekolah dasar SDN Kramat 1. Jenis penelitian yang digunakan adalah penelitian kualitatif. Data dikumpulkan dengan menggunakan wawancara mendalam, observasi dan mendeskripsikan penerapan Rencana Pelaksanaan Pembelajaran (RPP). Rencana pelaksanaan pembelajaran sangat diperlukan sejalan dengan beranekaragam corak perkembangan media pembelajaran serta sumber belajar disekitar sekolah yang dapat dimanfaatkan oleh guru dalam menunjang proses pembelajaran. Hasil penelitian ini menunjukkan bahwa,
\end{abstract}


implementasi Rencana Pelaksanaan Pembelajaran di Sekolah Dasar dilaksanakan secara terintegrasi, langkah-langkah guru dalam menerapkan RPP, sumber dan media yang digunakan pada saat mengajar, faktor yang mempengaruhi implementasi RPP dan diterapkan sesuai dengan RPP. Hasil penelitian ini diharapkan dapat bermanfaat dan menjadi acuan bagi para pendidik dan tenaga kependidikan untuk melakukan inovasi dalam rangka meningkatkan mutu pembelajaran siswa disekolah.

Keywords: RPP; implementasi; pembelajaran,

\section{PENDAHULUAN}

Pendidikan adalah bidang yang sangat penting dalam kehidupan suatu bangsa. Pendidikan membuat kita mampu mengikuti perkembangan zaman serta perubahanperubahan yang terjadi dalam bidang ilmu pengetahuan dan teknologi. Pendidikan sangat dibutuhkan untuk mempersiapkan calon peserta didik beradaptasi dengan perubahan sosial di masa depan. Masyarakat masa depan ditandai dengan perubahan yang cepat, yang ditandai dengan tren globalisasi yang kuat, perkembangan ilmu pengetahuan dan teknologi yang pesat, peningkatan kepadatan dan arus informasi yang cepat, serta perbaikan semua aspek kehidupan manusia layanan profesional (Pramita, Mulyati, \& Susanto, 2016).

Berdasarkan Undang-Undang Republik Indonesia Nomor 20 tahun 2003 tentang Sistem Pendidikan Nasional menerangkan bahwa pengertian "pendidikan adalah usaha sadar dan terencana untuk mewujudkan suasana belajar dan proses pembelajaran agar peserta didik secara aktif mengembangkan potensi dirinya untuk memiliki kekuatan spiritual keagamaan, pengendalian diri, kepribadian, kecerdasan, akhlak mulia, serta keterampilan yang diperlukan dirinya, masyarakat, bangsa dan negara" (Wiliandani, Wiyono, \& Sobri, 2016)

Adanya perencanaan, guru harus mampu memberikan pelajaran dengan metode belajar yang baik, seorang guru pula berpengaruh. Sesuai dengan ketentuan kurikulum pendidikan yang berlaku saat ini, guru harus mampu membuat data penyusunan dalam merancang desain pembelajaran yang menerapkan nilai-nilai karakter, yaitu jujur, cermat, patuh, dan lain sebagainya. Hal tersebut sesuai dengan tujuan pendidikan sebagaimana yang tertuang dalam UU RI Nomor 27 tahun 2003 menyatakan bahwa: "Dalam Sistem pendidikan Nasional Pasal 40 ayat 2 dikatakan bahwa Pendidik dan tenaga Kependidikan berkewajiban meciptakan suasana pendidikan yang bermakna, menyenangkan, kreatif, dinamis dan dialogis. Rencana pembelajaran itu disusun setiap kali pertemuan ataupun beberapa kali pertemuan yang didalamnya terdapat standar kompetensi, kompetensi dasar, indikator, materi pokok, alokasi waktu, dan lain sebagainya yang perlu dipaham bagi seorang guru" (Andriani, 1017).

Guru sebagai sumber daya manusia yang ada di sekolah mempunyai peran yang sangat menentukan dan merupakan kunci keberhasilan dalam mencapai tujuan institusi karena guru adalah pengelola pembelajaran bagi para siswa agar pembelajaran berjalan efektif dan efesien harus disediakan guru yang sesuai dengan kebutuhan sekolah, baik jumlah, kualifikasi maupun spesialisasi. Guru dipandang dapat memainkan peran penting 
terutama dalam membantu peserta didik untuk membangun sikap positif dalam belajar, membangkitkan rasa ingin tahu, mendorong kemandirian dan ketepatan logika intelektual, serta menciptakan kondisi-kondisi untuk sukses dalam belajar (Riptiani, Manuaba, \& Putra, 2015).

Pembelajaran adalah mengkomunikasikan secara tepat dan benar untuk menyampaikan informasinya yang disampaikan secara efektif, efektif dan efisien. Ciri utama desain pembelajaran adalah asumsi bahwa prinsip dan prosedur didasarkan pada hasil penelitian. Dari penelitian eksperimental terkontrol tradisional hingga penelitian pengembangan, hingga analisis kualitatif studi kasus, sifat penelitian bervariasi. Meskipun ide-ide desain alternatif sudah mulai bermunculan, namun tidak lepas dari dukungan atau pedoman teoritis yang kokoh.

Dalam kajian yang akan direncanakan, diperlukan berbagai teori untuk dirancang, agar rencana mata kuliah yang disusun benar-benar dapat memenuhi harapan dan tujuan pembelajaran, yang bertujuan untuk memenuhi kebutuhan rencana pembelajaran tersebut, dan dengan demikian mewujudkan peningkatan pembelajaran. Dalam peningkatan pembelajaran diasumsikan: untuk meningkatkan kualitas pembelajaran, sebelum itu desain pembelajaran harus ditingkatkan. Rencana pembelajaran dapat digunakan sebagai titik awal untuk meningkatkan kualitas pembelajaran. Hal ini dimungkinkan karena dalam desain pembelajaran, mulai dari analisis tujuan pembelajaran hingga pelaksanaan penilaian sumatif, semua tahapan pengajaran guru telah dirancang dengan cermat.

Didalam pembelajaran ialah diarahkan pada kemudahan belajar, Pembelajarannya yang merupakan upaya membelajarkan siswa dan perancangan pembelajaran merupakan penataan upaya tersebut agar muncul prilaku belajar. Dalam kondisi yang ditata dengan baik strategi yang direncanakan akan memberikan peluang dicapainya hasil pembelajaran. Di sinilah peran guru mendesain pembelajaran secara terencana sehingga dapat mempermudah melakukan kegiatan pembelajaran. Jika ini dilakukan dengan baik maka sasaran akhir adalah memudahkan belajar siswa dapat tercapai (Suparman Atwi, 2012).

Didalam secara Proses pembelajaran merupakan sebuah proses yang mampu menumbuh kembangkan pengetahuan peserta didik dan memberikan pengalaman yang nyata bagi peserta didik. Sehingga dalam kegiatan proses pembelajaran itu terjadi peserta didik dapat merasakan pengalaman tersebut bagi dirinya sendiri.Baik itu langsung maupun tidak langsung terhadap dirinya dalam proses pembelajaran. Salah satu cara dalam menciptakan proses pembelajaran yang efektif dan efisien adalah dengan mendesain pembelajaran dengan mengimplementasikan model serta menggunakan konsep pembelajaran yang akan dilakukan dalam proses pembelajaran implementasi desain pembelajaran dalam kegiatan mengajar disekolah dasar (Iskandar \& F, 2020).

Kegiatan pembelajaran merupakan salah satu hal pokok dari keseluruhan proses pendidikan. Salah satu komponen yang memegang peranan penting dalam proses pembelajaran adalah guru. Guru berperanan sebagai ujung tombak dalam pencapaian tujuan pendidikan, Oleh karena itu, guru diharapkan mampu sebagai pengelola yang dapat menciptakan hubungan baik antara guru dengan siswa, siswa dengan siswa, guru dengan guru serta masyarakat sekitarnya yang akhirnya tercipta interaksi yang harmonis demi pencapaian tujuan pendidikan (Sudirman \& Maru, 2016).

Pengembangan kurikulum merupakan salah satu proses yang kompleks dan melibatkan berbagai komponen yang saling terkait satu dengan yang lainnya (Mulyasa, 2015). Pemerintah harus selalu mengembangkan serta memperbaharui kurikulum untuk meningkatkan mutu sumber daya manusia. Kurikulum senantiasa harus bisa mengikuti perkembangan zaman dan mampu memenuhi tuntutan di masa yang akan datang. Perubahan kurikulum hendaknya dipersiapkan di berbagai aspek agar pelaksanaannya tidak menimbulkan masalah dikemudian hari. Implementasi kurikulum 2013 menuntut 
guru untuk mengelola pembelajaran secara efektif. Keikutsertaan siswa secara aktif dalam kegiatan belajar mengajar merupakan konsekuensi logis dari pengajaran yang sebenarnya, bahkan merupakan faktor yang penting dalam hakikat kegiatan belajar mengajar (Pramita et al., 2016)

Hal senada juga diungkapkan oleh Dewey (1966) bahwa para siswa harus terlibat aktif di dalam pembelajaran, bukan hanya menerima informasi secara pasif. Suatu pengajaran tidak akan berhasil tanpa keaktifan siswa.

RPP merupakan alat yang digunakan guru untuk memandu kegiatan belajar siswa untuk mencapai kemampuan dasar (KD). RPP yang digunakan guru dalam proses pembelajaran bisa memperkuat pembentukan ide tentang pengajaran dan praktik di kelas. Rencana pengajaran yang baik harus memasukkan dan mencerminkan pengetahuan dan keterampilan guru Terkait penerapan RPP. Kegiatan pembelajaran yang dirancang pada RPP harus dapat mengembangkan potensi peserta didik agar tercapai keseimbangan dalam sikap, pengetahuan, dan keterampilan sesuai dengan karakteristik Kurikulum 2013.

Kurikulum 2013 membawa perubahan mendasar peran guru dalam pembelajaran. Secara administratif, pemerintah pusat telah menyiapkan perangkat pelaksanaan pembelajaran yang tidak perlu lagi disiapkan oleh guru. Namun demikian, guru dituntut berperan secara aktif sebagai motivator dan fasilitator pembelajaran sehingga siswa akan menjadi pusat belajar. Hal ini menjadi kendala tersendiri bagi para guru karena tidak semua guru memiliki kompetensi tersebut. Selain itu, guru dituntut kesiapannya untuk melaksanakan kurikulum dalam waktu yang relatif singkat sementara perangkatnya belum disiapkan secara matang (Krissandi, 2018).

Berdasarkan hasil wawancara peneliti pada bulan Januari tahun 2021 terhadap guru kelas VI di SDN Kramat I ditemukan bahwa seorang guru mengajar sesuai susunan RPP dan langkah-langkah yang diterapkan dikelas serta masih ditemukannya faktor yang dapat mempengaruhinya implementasi RPP yaitu kurangnya kompetensi siswa dari segi kemampuan memahami, nalar maupun intelektual.

Berdasarkan pentingnya pengetahuan guru tentang kurikulum, pentingnya peranan RPP dalam pelaksanaan Kurikulum 2013, dan informasi yang telah dimiliki terkait pengetahuan guru tentang Kurikulum 2013, maka penelitian ini bertujuan untuk mengetahui pengetahuan pendidik atau calon pendidik tentang Kurikulum 2013 dalam penyusunan RPP.

Oleh karena itu, penulis melakukan peneleitian yang bertujuan yang meliputi (1) memahami dan mendeskripsikan implementasi RPP di sekolah, (2) memahami metode pembelajaran (3) bagaimana strategi pembelajaran yang digunakan oleh guru, (4) apa saja sumber dan media belajar, (5) apa saja faktor yang dapat mempengaruhi implementasi RPP.

\section{METODE PENELITIAN}

Penelitian ini merupakan penelitian kualitatif. penelitian kualitatif yang dituangkan kedalam bentuk uraian kata-kata jadi tidak menggunakan angka-angka statistik. Penelitian kualitiatif dapat dikatakan sebagai prosedur penelitian yang menghasilkan data deskriptif baik berupa kata-kata maupun lisan dari orang-orang dan prilaku yang dapat diamati (Ulfatin, 2104). Penelitian ini mendeskripsikan penerapan Rencana Pelaksanaan Pembelajaran (RPP). Penelitian deskriptif kualitatif ini dilaksanakan pada guru kelas VI bagaimana mengimplementasikannya (merencanakan, melaksanakan, sumber dan media , metode serta strategi pembelajaran), dan apa saja faktor pendukung dan penghambatnya.

Peneliti hadir dilokasi penelitian yaitu SDN Kramat I Kabupaten Tangerang, melakukan perencanaan, pelaksanaan, dan menyusun pelaporan hasil penelitiannya. Pada 
penelitian ini instrumen utama adalah peneliti. peneliti meninjau seluruh susunan bagian pada RPP yang dibuat oleh guru tersebut dengan secara cermat, benar dan tepat sesuai fokus penelitian yaitu implementasi Rencana Pelaksanaan Pembelajaran (RPP).

Peneliti akan dapat mengenal subjek penelitian secara pribadi dan lebih dekat melalui pendekatan kualitatif ini. Hal ini dikarenakan peneliti terlibat langsung dalam menggali informasi yang berkaitan dengan situasi, kondisi, dan peristiwa mengenai kendala serta strategi yang dilakukan guru dalam mengimplementasikan RPP.

Sasaran penelitian yaitu, sebagian secara langsung mendatangi sekolahan tersebut untuk melakukan wawancara dan berdialog. Hasil wawancara dan konfirmasi implementasi Rencana Pelaksanaan Pembelajaran (RPP) dikembangkan secara terbuka namun tetap memakai kendali yakni melalui triangulasi, pengecekan ulang informasi dari satu subyek pada subyek lain.

\section{HASIL DAN PEMBAHASAN}

Berdasarkan hasil wawancara dengan guru kelas VI SDN Kramat 1, didapatkan informasi bahwa pada hasil observasi dilakukan seorang guru mengimplementasikan RPP (Rencana Pelaksanaan Pembelajaran) dibuat agar guru mudah dalam mengajar dan lebih terarah.

Langkah-langkah mengimplementasikan Rencana Pelaksanaan Pembelajaran (RPP) adalah pertama, sebelum memulai pembelajaran siswa diharuskan membaca buku yang ingin ia baca selama 15 menit sebelum pembelajaran dimulai. Tujuannya agar siswa gemar membaca. Ketika sudah memasuki pembelajaran guru mereview keterkaitan pembelajaran yang lalu hingga sekarang yang akan dipelajari. Sebelum melakukan Kegiatan Belajar Mengajar (KBM) siswa diarahkan untuk bernyanyi dan membaca motto kelas agar terciptanya rasa semangat sebelum belajar dan mengelola kelas serta memfokuskan peserta didik agar siap menerima pembelajaran. Dalam kurikulum 2013 pembelajaran harus tercipta aktif dan menyenangkan dan bagaimana siswa mengikuti pembelajaran dengan siap menerima. Kedua, masuk ke kegiatan inti yaitu mengajar sesuai materi yang telah disusun di RPP. Ketiga, kegiatan inti selesai dilanjut dengan kegiatan penutup refleksi berupa tanya jawab terkait materi yang dipelajari hari ini. Berdasarkan Permendikbud RI No. 81A tahun 2013 (Fallis, 2013) menerangkan mengenai standar proses pelaksanaan dalam pembelajaran terdiri atas kegiatan pendahuluan, kegiatan inti, dan kegiatan penutup. Pada bagian kegiatan pendahuluan terdiri atas (1) mempersiapkan siswa secara mental dan fisik; (2) melakukan apersepsi; (3) menyajikan permasalahan atau tugas yang akan dilakukan; (4) menyajikan cakupan materi beserta penjelasannya tentang kegiatan-kegiatan yang akan dilakukan oleh siswa. Pada kegiatan inti, proses pembelajaran yang dilakukan harus interaktif, inspiratif, menyenangkan, menantang, memotivasi, dan memberikan ruang kepada siswa untuk memiliki kreasi sendiri yang disesuaikan dengan bakat, minat, dan perkembangan psikologis maupun fisik. Dalam kegiatan siswa, guru harus memperhatikan kompetensikompetensi yang terkait dengan sikap sesuai dengan RPP yang telah dirancang. Pada kegiatan penutup, guru dan siswa membuat rangkuman mengenai pelajaran, melakukan kegiatan penilaian, merencanakan tindak lanjut, serta menyampaikan rencana untuk pembelajaran berikutnya. (Demonika, Mustadi, \& Rezkillah, 2020)

Untuk menerapkan Rencana Pelaksanaan Pembelajaran (RPP) perlu menentukan metode yang sesuai dengan peserta didik. Metode yang digunakan yaitu dalam mengajar guru tidak hanya menerapkan 1 metode tetapi 2 metode atau lebih, karena setiap anak memiliki karakteristik dan kemampuan yang berbeda. Seorang guru tidak boleh menyamaratakan semua kemampuan peserta didik. 
Strategi pembelajaran yag digunakan guru adalah guru sebagai pengembang media pembelajaran harus mengetahui perbedaan pendekatan-pendekatan dalam belajar agar dapat memilih strategi 6 Perencanaan Pembelajaran di Sekolah Dasar pembelajaran yang tepat. Strategi pembelajaran harus dipilih untuk memotivasi para pembelajar, memfasilitasi proses belajar, membentuk manusia seutuhnya, melayani perbedaan individu, mengangkat belajar bermakna, mendorong terjadinya interaksi, dan memfasilitasi belajar kontekstual, Jika menelaah literatur psikologi, kita akan menemukan banyak teori belajar yang bersumber dari aliran-aliran psikologi. Dalam tautan di bawah ini akan dikemukakan empat jenis teori belajar, yaitu: (A) teori belajar behaviorisme; (B) teori belajar kognitivisme; (C) teori belajar konstruktivisme; (D) teori belajar humanisme, dan (E) teori belajar gestalt.

Tujuan dalam pembuat RPP adalah untuk meningkatkan mutu pendidikan disekolah dan untuk meningkatkan kompetensi peserta didik dikelas. Disusunnya Kurikulum 2013 bertujuan untuk mempersiapkan insan Indonesia untuk memiliki kemampuan hidup sebagai pribadi dan warga negara yang produktif, kreatif, inovatif dan afektif serta mampu berkontribusi pada kehidupan bermasyarakat, berbangsa, bernegara dan peradaban dunia. Ketika guru tidak dapat melaksanakan tugas, peran, dan fungsinya sesuai amanat kurikulum baik dikarenakan faktor internal dari diri guru sendiri maupun faktor eksternal seperti dari sekolah tempatnya mengajar maupun pemerintah, maka harapan dari perubahan kurikulum berikut pula tujuan dari kurikulum itu sendiri juga sulit untuk terwujud. (Melati \& Utanto, 2016)

Sumber dan media belajar yang digunakan seorang guru yaitu buku tematik dan media teknologi melalui internet, terkait materi yang akan dipelajari. Serta menggunakan media benda konkret, visual, maupun audio-visual. Media yang dibuat sedemikian rupa apa yang berada disekeliling lingkungannya.

Faktor yang dapat mempengaruhi penerapan RPP yaitu ada 2 faktor yaitu faktor internal dan faktor eksternal. faktor internal yang pertama, kompetensi siswa. Setiap siswa mempunyai daya kemampuan, karakateristik dan nalar berbeda. Kedua, guru yang kurang inovatif, kreatif, dan salah dalam menggunakan metode ataupun media pembelajaran yang ingin di implementasikan. Faktor eksternal yaitu fasilitas sekolah yang kurang memadai untuk menerapkan pembelajaran yang sudah dirancang sedemikian rupa agar bisa diterapkan dikelas.

Oleh karena itu, sebagai guru perlu melakukan suatu ide, inovasi dan kreativitas dalam mengembangakan metode, sumber belajar, media, dan strategi pembelajaran agar dapat meningkatkan mutu pendidikan di sekolah. Pada era modern saat ini guru juga perlu melakukan trobosan terbaru terkait metode mengajar dan media pembelajaran, sebab semakin berkembangnya zaman siswapun terkadang merasa bosan dan jenuh ketika seorang guru menerapkan metode mengajar yang lama (ceramah) dan monoton. Dengan adanya penelitian ini diharapkan guru-guru dapat mengembangkan pembelajaran yang menyenangkan dan menarik bagi para siswa.

Permendikbud No 22 Tahun 2016 menyatakan bahwa proses pembelajaran pada satuan pendidikan harus diselenggarakan secara interaktif, inspiratif, menyenangkan, menantang, memotivasi peserta didik untuk berpatisipasi aktif serta memberikan ruang yang cukup bagi kreativitas, kemandirian sesuai bakat, minat serta perkembangan peserta didik. Pada proses penerapan pelaksanaan pembelajaran setiap satuan pendidikan dituntut untuk mampu melakukan perencanaan pembelajaran dengan baik, sehingga pelaksanaan proses pembelajaran dapat berjalan semaksimal mungkin serta penilaian proses pembelajaran bisa diarahkan untuk meningkatkan efesiensi dan efektifitas ketercapaian kompetensi lulusan (Iskandar \& F, 2020).

Mengimplementasikan program pembelajaran yang sudah dituangkan di dalam silabus, guru harus menyusun Rencana Pelaksanaan Pembelajaran (RPP). RPP 
merupakan pegangan bagi guru dalam melaksanakan pembelajaran baik di kelas, laboratorium, atau lapangan untuk setiap kompetensi dasar. Oleh karena itu, apa yang tertuang di dalam RPP berkarakter memuat hal-hal yang langsung berkaitan dengan aktivitas pembelajaran dalam upaya pencapaian penguasaan suatu kompetensi dasar (Andriani, 1017).

Pada hakikatnya penyusunan RPP bertujuan merancang pengalaman belajar siswa untuk mencapai tujuan pembelajaran. Tidak ada alur pikir (algoritma) yang spesifik untuk menyusun suatu RPP, karena rancangan tersebut seharusnya kaya akan inovasi sesuai dengan spesifikasi materi ajar dan lingkungan belajar siswa (sumber daya alam dan budaya lokal, kebutuhan masyarakat serta perkembangan ilmu pengetahuan dan teknologi). Pengalaman dari penilaian portofolio sertifikasi guru ditemukan, bahwa pada umumnya RPP guru cenderung bersifat rutinitas dan kering akan inovasi. Mengapa? diduga dalam melakukan penyusunan RPP guru tidak melakukan penghayatan terhadap jiwa profesi pendidik. Keadaan ini dapat dipahami karena, guru terbiasa menerima borang-borang dalam bentuk format yang mengekang guru untuk berinovasi dan penyiapan RPP cenderung bersifat formalitas. Bukan menjadi komponen utama untuk sebagai acuan kegiatan pembelajaran. Sehingga ketika otonomi pendidikan dilayangkan tak seorang gurupun bisa mempercayainya. Buktinya perilaku menyusun RPP dan perilaku mengajar guru tidak berubah jauh. Acuan alur pikir yang dapat digunakan sebagai alternatif adalah:

1. Kompetensi apa yang akan dicapai.

2. Indikator-indikator yang dapat menunjukkan hasil belajar dalam bentuk perilaku yang menggambarkan pencapaian kompetensi dasar.

3. Tujuan pembelajaran yang merupakan bentuk perilaku terukur dari setiap indikator.

4. Materi dan uraian materi yang sesuai dengan kebutuhan belajar siswa agar dapat mencapai tujuan pembelajaran.

5. Metode-metode yang akan digunakan dalam pembelajaran.

6. Langkah-langkah penerapan metode-metode yang dipilih dalam satu kemasan pengalaman belajar.

7. Sumber dan media belajar yang terkait dengan aktivitas pengalaman belajar siswa. 8 . Penilaian yang sesuai untuk mengukur ketercapaian tujuan pembelajaran.

Secara umum, ciri-ciri Rencana Pelaksanaan Pembelajaran (RPP) yang baik adalah sebagai berikut:

1. Memuat aktivitas proses belajar mengajar yang akan dilaksanakan oleh guru yang akan menjadi pengalaman belajar bagi siswa.

2. Langkah-langkah pembelajaran disusun secara sistematis agar tujuan pembelajaran dapat dicapai.

3. Langkah-langkah pembelajaran disusun serinci mungkin, sehingga apabila RPP digunakan oleh guru lain (misalnya, ketiga guru mata pelajaran tidak hadir), mudah dipahami dan tidak menimbulkan penafsiran ganda.

Petunjuk Pengisian Format RPP, dapat di jelaskan sebagai berikut:

1. Tuliskan identitas

RPP terdiri dari: Nama sekolah, Mata Pelajaran, Kelas/Semester, Standar Kompetensi, Kompetensi Dasar, Indikator dan Alokasi Waktu (lihat format RPP pada lampiran).

Catatan:

a. RPP disusun untuk satu Kompetensi Dasar.

b. Standar Kompetensi, Kompetensi Dasar, dan Indikator dikutip dari silabus yang disusun dan telah diberlakukan dalam suatu satuan pendidikan (SD/MI, SMP/MTs, SMA/MA/SMK). 
Menjadi perhatian: Standar kompetensi-kompetensi dasar-indikator adalah suatu alur pikir yang saling terkait tidak dapat dipisahkan.

Indikator adalah perilaku (bukti terukur) yang dapat memberikan gambaran bahwa siswa telah mencapai kompetensi dasar.

Kompetensi Dasar adalah sejumlah kompetensi yang memberikan gambaran bahwa siswa telah mencapai standar kompetensi.

c. Indikator merupakan:

1) Penanda pencapaian kompetensi dasar yang ditandai oleh perubahan perilaku yang dapat diukur yang mencakup sikap, pengetahuan, dan keterampilan.

2) Dikembangkan sesuai dengan karakteristik peserta didik, satuan pendidikan, dan potensi daerah.

3) Rumusannya menggunakan kerja operasional yang terukur dan/atau dapat diobservasi.

4) Digunakan sebagai dasar untuk menyusun alat penilaian.

5) Disusun dengan kalimat operasional (dapat diukur) berisi komponen $\mathrm{ABCD}$ (Audience $=$ Siswa, Behavior $=$ Perilaku, Competency $=$ Kompetensi dan Degree $=$ peringkat/ukuran).

d. Alokasi waktu diperhitungkan untuk pencapaian satu kompetensi dasar, dinyatakan dalam jam pelajaran dan banyaknya pertemuan (contoh: 2 x 40 menit). Karena itu, waktu untuk mencapai suatu kompetensi dasar dapat diperhitungkan dalam satu atau beberapa kali pertemuan bergantung pada karakteristik kompetensi dasarnya. (Afandi \& Barudin, 2011)

Bahan ajar yang akan digunakan dalam proses pembelajaran dalam konteks Kurikulum 2013 memang tidaklah jauh berbeda dengan bahan ajar KTSP. Namun demikian sejalan dengan kenyataan bahwa Kurikulum 2013 menitikberatkan pada penyederhanaan konten kurikulum dan penerapan pembelajaran tematik-integratif (khususnya pada jenjang SD). Khusus pembelajaran di sekolah adsar yang berbasis pada pembelajaran tematik-integratif, buku tidak disusun berdasarkan materi pelajaran (kecuali buku Pendidikan Agama dan Budi Pekerti) melainkan berdasarkan tema sehingga setiap tahun ajaran siswa akan menerima sejumlah buku berdasarkan tema yang digunakan. Upaya penerbitan buku tematik ini merupakan wujud keseriusan pemerintah dalam mengimplementasikan pembelajaran tematikintegratif yang selama ini masih terkesan setengah-setengah sebab pemberlakuannya tidak disertai dengan buku tematik yang sebenarnya.

Pembelajaran tematik atau model pembelajaran tematik terpadu pada kurikulum 2013 dilaksanakan pada jenjang Sekolah Dasar (SD). Model pembelajaran ini berangkat dari pendekatan tematis sebagai acuan dasar bahan dan kegiatan pembelajaran. Tema yang dibuat dapat mengikat kegiatan pembelajaran, baik dalam mata pelajaran tertentu maupun antar mata pelajaran. (Rohmah Julianti \& Mawardi, 2018)

Kegiatan pembelajaran, dalam implementasinya mengenal banyak istilah untuk menggambarkan cara mengajar yang akan dilakukan oleh guru. Saat ini, begitu banyak macam strategi ataupun metode pembelajaran yang bertujuan untuk meningkatkan kualitas pembelajaran menjadi lebih baik. Berikut penjelasan tentang istilah Inovasi Model Pembelajaran sesuai Kurikulum 201319 pendekatan, model, strategi, metode, teknik, dan taktik dalam pembelajaran (Nurdyansyah \& Fahyuni, 2016).

2. Tujuan Pembelajaran

Tuliskan output (hasil langsung) dari satu paket pengalaman belajar yang dikemas oleh guru, karena itu penetapan tujuan pembelajaran dapat mengacu pada 
pengalaman belajar siswa. Pengalaman belajar: Mendapat informasi tentang sistem peredaran darah pada manusia dan mengkomunikasikan kepada sesama siswa di kelas.

Tujuan pembelajaran, boleh salah satu di antara atau keseluruhan tujuan pembelajaran berikut:

1) Siswa dapat menjawab pertanyaan guru berikut:

a. Organ apa saja yang termasuk ke dalam alat-alat peredaran darah.

b. Sebutkan bagian-bagian jantung.

c. Deskripsikan mekanisme peredaran darah pada manusia.

2) Siswa dapat merespon dengan baik pertanyaan-pertanyaan yang diajukan oleh teman-teman sekelasnya.

3) Siswa dapat mengulang kembali informasi tentang peredaran darah yang telah disampaikan oleh guru.

4) Bila pembelajaran dilakukan lebih dari 1 (satu) pertemuan, ada baiknya tujuan pembelajaran juga dibedakan menurut waktu pertemuan, sehingga target-target produk tiap pembelajaran jelas kelihatan.

3. Materi Pembelajaran

Materi pembelajaran adalah materi yang digunakan untuk mencapai tujuan pembelajaran dan indikator. Materi dikutip dari materi pokok yang ada dalam silabus. Materi pokok tersebut kemudian dikembangkan menjadi beberapa uraian materi. Untuk memudahkan penetapan uraian materi dapat diacu dari indikator.

4. Metode Pembelajaran

Metode dapat diartikan benar-benar sebagai metode, tetapi dapat pula diartikan sebagai model atau pendekatan pembelajaran, bergantung pada karakteristik pendekatan dan/atau strategi yang dipilih.

Karena itu pada bagian ini cantumkan pendekatan pembelajaran dan metodemetode yang diintegrasikan dalam satu pengalaman belajar siswa:

1) Pendekatan pembelajaran yang digunakan, misalnya: pendekatan proses, kontekstual, pembelajaran langsung, pemecahan masalah, dan sebagainya.

2) Metode-metode yang digunakan, misalnya: ceramah, inquiri, observasi, tanya jawab, dan seterusnya.

Perkembangan kurikulum memerlukan berbagai persiapan, salah satunya adalah persiapan guru sebagai tenaga kependidikan utama yang mengembangkan ide dan rancangan pembelajaran untuk disampaikan kepada siswa sehingga siswa memahami pembelajaran yang disesuaikan dengan tuntutan kurikulum 2013 (Riana, Agung, \& Parmiti, 2016).

Kurikulum 2013 adalah kurikulum terbaru dalam pendidikan di Indonesia. Pada periode sebelumnya, Indonesia menerapkan Kurikulum Tingkat Satuan Pendidikan (KTSP) di semua sekolah. Pada tahun 2013, terjadi penggantian kurikulum dari kurikulum KTSP menjadi Kurikulum 2013. Pengembangan kurikulum 2013 ini menitikberatkan pada pengembangan karakter, sehingga diharapkan dapat menghasilkan lulusan yang kreatif, produktif, miliki inovatif, berkarakter dan memiliki daya saing dengan dengan bangsa lain (Badiah, 2020).

\section{KESIMPULAN}

Berdasarkan Undang-Undang Republik Indonesia Nomor 20 tahun 2003 tentang Sistem Pendidikan Nasional menerangkan bahwa pengertian «pendidikan adalah usaha sadar dan terencana untuk mewujudkan suasana belajar dan proses pembelajaran agar 
peserta didik secara aktif mengembangkan potensi dirinya untuk memiliki kekuatan spiritual keagamaan, pengendalian diri, kepribadian, kecerdasan, akhlak mulia, serta keterampilan yang diperlukan dirinya, masyarakat, bangsa dan negara».

RPP merupakan alat yang digunakan guru untuk memandu kegiatan belajar siswa untuk mencapai kemampuan dasar. RPP yang digunakan guru dalam proses pembelajaran bisa memperkuat pembentukan ide tentang pengajaran dan praktik di kelas. Rencana pengajaran yang baik harus memasukkan dan mencerminkan pengetahuan dan keterampilan guru Terkait penerapan RPP. Kegiatan pembelajaran yang dirancang pada RPP harus dapat mengembangkan potensi peserta didik agar tercapai keseimbangan dalam sikap, pengetahuan, dan keterampilan sesuai dengan karakteristik Kurikulum 2013.

Mengimplementasikan program pembelajaran yang sudah dituangkan di dalam silabus, guru harus menyusun Rencana Pelaksanaan Pembelajaran (RPP). RPP merupakan pegangan bagi guru dalam melaksanakan pembelajaran baik di kelas, laboratorium, atau lapangan untuk setiap kompetensi dasar. Oleh karena itu, apa yang tertuang di dalam RPP berkarakter memuat hal-hal yang langsung berkaitan dengan aktivitas pembelajaran dalam upaya pencapaian penguasaan suatu kompetensi dasar.

Kurikulum 2013 adalah kurikulum terbaru dalam pendidikan di Indonesia. Pada periode sebelumnya, Indonesia menerapkan Kurikulum Tingkat Satuan Pendidikan (KTSP) di semua sekolah. Pada tahun 2013, terjadi penggantian kurikulum dari kurikulum KTSP menjadi Kurikulum 2013. Pengembangan kurikulum 2013 ini menitikberatkan pada pengembangan karakter, sehingga diharapkan dapat menghasilkan lulusan yang kreatif, produktif, miliki inovatif, berkarakter dan memiliki daya saing dengan dengan bangsa lain.

\section{BIBLIOGRAPHY}

Afandi, M., \& Barudin. (2011). Perencanaan Pembelajaran Di Sekolah Dasar Dengan Memasukan Pendidikan Budaya dan Karakter Bangsa (1st ed.). Bandung: Alfabeta, cv.

Andriani, N. (1017). Implementasi Rencana Pelaksaan Pembelajaran (RPP) Yang Berkatakter Pada Mata Pelajaran Ipa Terpadu. Prosiding Seminar Nasional Pendidikan, (November), 257-269.

Badiah, L. I. (2020). Studi Deskriptif Implementasi Kurikulum 2013 Untuk Anak. Jurnal Pendidikan Dan Ilmu Pengetahuan, 20(2), 184-188.

Demonika, shelvia devi, Mustadi, A., \& Rezkillah, inang irma. (2020). Implementasi Kurikulum 2013 Di Sekolah Dasar. Jurnal Pendidikan: Teori, Penelitian, Dan Pengembangan, 5, 817-821.

Dewey, J. 1966. Democracy and Education: An Introduction to the Philosophy of Education. New York: Free Press. 296 Jurnal Pendidikan, Vol. 1 No. 3, Bln Maret, Thn 2016, Hal 289-296Glynn.

Iskandar, R., \& F, F. (2020). Implementasi Model ASSURE untuk Mengembangkan Desain Pembelajaran di Sekolah Dasar. Jurnal Basicedu, 3(2), 524-532.

Krissandi, apri damai sagita. (2018). Persepsi Guru Sekolah Dasar Terhadap Keberhasilan Implementasi Kurikulum 2013. 5(1), 79-89. 
Melati, E. R., \& Utanto, Y. (2016). Kendala Guru Sekolah Dasar dalam Memahami Kurikulum 2013. Indonesian Journal of Curriculum and Educational Technology Studies, 4, 1-9.

Nurdyansyah, \& Fahyuni, E. F. (2016). Inovasi Model Pembelajaran. In Nizmania Learning Center (1st ed.). Sidoarjo: Nizamia Learning Center.

Pramita, M., Mulyati, S., \& Susanto, H. (2016). Implementasi Desain Pembelajaran pada Kurikulum 2013 dengan Pendekatan Kontekstual. Jurnal Pendidikan, 1(3), 289— 296.

Riana, I. G. A., Agung, A. A. G., \& Parmiti, D. P. (2016). Analisis Rencana Pelaksanaan Pembelajaran ( Rpp ) Untuk Implementasi Kurikulum 2013 Di Sd Negeri 3 Banjar Jawa Kecamatan Buleleng Tahun Pelajaran 2015/2016. E-Journal Edutech Universitas Pendidikan Ganesha, 5(2).

Riptiani, K. M., Manuaba, I. B. S., \& Putra, M. (2015). Studi Evaluasi Implementasi Kurikulum 2013 Ditinjau Dari Cipp Pada Sekolah Dasar Negeri Di Wilayah Pedesaan Kabupaten Badung. E-Journal PGSD Universitas Pendidikan Ganesha, $3(1)$.

Rohmah Julianti, I. A., \& Mawardi. (2018). Penerapan Desain Pembelajaran Tematik Integratif Alternatif Berbasis Sub-subtema untuk Meningkatkan Kebermaknaan dan Hasil Belajar. Publikasi Pendidikan, 8(3), 206.

Sudirman \& Maru, R. (2016). Implementasi Model-Model Pembelajaran dalam Bingkai Penelitian Tindakan Kelas (2nd ed.; S. Nyompa, ed.). Makassar: Badan Penerbit Universitas Negeri Makassar.

Suparman Atwi, M. (2012). Desain Instrusional Modern; Panduan Para Pengajar dan Inovator Pendidikan (4th ed.; Novietha I. Sallama, ed.). Jakarta: Erlangga.

Wiliandani, A. M., Wiyono, B. B., \& Sobri, A. Y. (2016). Implementasi Pendidikan Karakter dalam Pembelajaran di Sekolah Dasar. 4(3), 132-142. Retrieved from http://journal.um.ac.id/index.php/jp 